๑ Entomologica Fennica. 15 June 2001

\title{
A scuttle fly (Diptera: Phoridae) parasitizing a beetle (Coleoptera: Chrysomelidae) in Russia
}

\author{
R. Henry L. Disney, Elena L. Zvereva \& Mikhail B. Mostovski
}

Disney, R. H. L., Zvereva, E. L. \& Mostovski, M. B. 2001: A scuttle fly (Diptera: Phoridae) parasitizing a beetle (Coleoptera: Chrysomelidae) in Russia. - Entomol. Fennica 12: 59-63.

Megaselia opacicornis Schmitz is reported parasitizing the pupae of Melasoma lapponica (L.). The hitherto unknown male of the fly is described and the recognition of the female clarified. Life history data are summarised.

R. H. L. Disney, University Museum of Zoology, Downing Street, Cambridge CB2 3EJ, England

Elena L. Zvereva, Section of Ecology, University of Turku, FIN-20014 Turku, Finland

M. B. Mostovski, Palaeaontological Institute, 123 Profsoyuznaya Str., Moscow, 117868 GSP, Russia

Received 6 May 1999, accepted 28 December 2000

\section{Introduction}

Most records of Phoridae reared from beetles are cases of moribund individuals of the 'host' species utilised by the larvae of saprophage phorid species (e.g. Durska \& Disney 1998). The notable exceptions are the parasitization of the pupae of Coccinellidae (Disney 1994, Disney et al. 1994), of the adults of Cantharidae (Borgmeier 1958, Brown 1996b) and of Lampyridae (Lloyd 1973, Lewis \& Monchamp 1994, Brown 1996a), and the parasitization of the pupae of the chrysomelid Chrysomela aenea L. (= Melasoma aenea L.) by Megaselia rubricornis (Schmitz) (Kanervo 1946). A second possible case reported an unidentified phorid reared from the larvae and/or pupae of the chrysomelid Melasoma populi L. (Devantoy 1948), but it is difficult to assess as to whether this was a case of parasitoidism or exploitation of moribund hosts by a saprophage species. However, a further definite case of the parasitization of the pupae of a chrysomelid involves M. lapponica (L.) in Russia. Initially, the phorid species involved was also attributed to M. rubricornis (Zvereva et al. 1995, 1997). However, since then further specimens were submitted to MBM, who in turn passed a sample to RHLD. The latter concluded that they were not M. rubricornis. In the present paper we report that this fly is Megaselia opacicornis Schmitz and provide fuller details on its biology.

\section{Megaselia opacicornis Schmitz (Figs. 1-3)}

Megaselia opacicornis Schmitz, 1949: 79.

Material examined (by RHLD): Holotype female, Sweden, Lapland, Abisko, July 1948 (H. Franz) (Museum Koenig, Bonn). 7 males, 4 females, Russia, Kolsky (Kola) Peninsula, Murmansk Region, near Monchegorsk, August 1997, emerged from pupae of Melosoma lapponica (E. L. Zvereva) (University Museum of Zoology, Cambridge). In addition, MBM has retained 12 males, 16 females and 12 puparia in the Palaeon- 


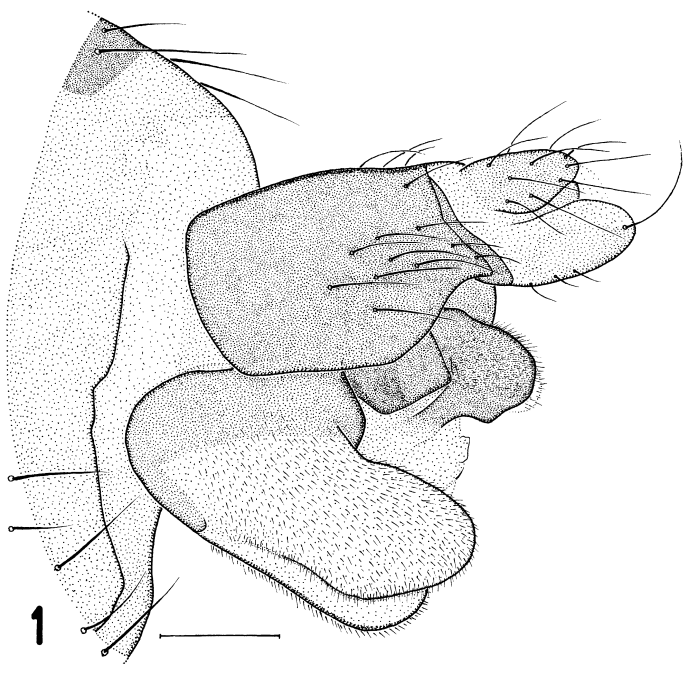

Fig. 1. Megaselia opacicornis male, left face of hypopygium. Scale bar $=0.1 \mathrm{~mm}$.

tological Institute in Moscow.

This species was described from the single holotype female. This is now badly damaged, but has been remounted on a slide by RHLD. While it lies at the lower end of the range of variation in size (see below) it is evidently conspecific with the females from Russia.

Schmitz \& Delage (1981) reported a second female, collected in 1957 (by P. I. Persson), from the type locality. This has also been remounted on a slide by RHLD. It proves to belong to an entirely different species, distinguished at once by the lobes at the rear of abdominal sternum 8 having the minute fine hairs up to, and overreaching, their hind margins.

Megaselia opacicornis is variable in size, presumably related to the variation in the number of larvae per host pupa (see below) and a consequential variation in the size of the mature larvae at the time of pupariation. It is also variable in details such as chaetotaxy and costal ratios. While the females have three bristles on the notopleuron the males have either two or three, but usually three. When there are only two it is the middle one that is reduced or absent. In the keys to males of the British species (Disney 1989) M. opacicornis readily runs to couplet 153 . Those with three notopleurals run to couplet 154 , but the anal tube being clearly shorter than the midline length of

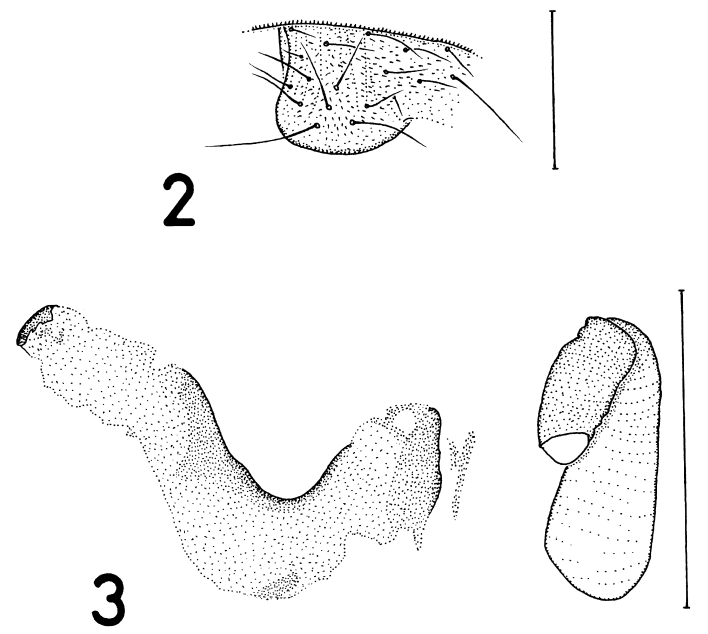

Figs 2-3. Megaselia opacicornis female. (2) Left lobe at rear of sternum of abdominal segment 8 ; (3) furca (sternite 9) and putative spermatheca (to right). Scale bars $=0.1 \mathrm{~mm}$.

the epandrium will immediately distinguish this species. Specimens with only two notopleurals will run to couplet 160 . The simple hairs at the tip of the proctiger and the relatively large third antennal segment (diameter about $0.15 \mathrm{~mm}$ ) means that these males agree with neither lead. The details of the hypopygium will further distinguish this species.

In the key to pinned specimens of the relevant section of Palaearctic species (Schmitz \& Delage 1981) both the males and females will run to couplet 27 and not to 22, which is where $M$. opacicornis was placed. This is because at couplet 20 one may only proceed to 22 by assenting to the arista being shorter than the midline length of the frons and to the intra-alar bristles being obscure. In fact the arista is longer than the frons, albeit being relatively short for the genus, and the intraalars are well developed. However, in the holotype these bristles have fallen off, but their basal sockets are of the normal size. The other species running out at couplet 22 is the chrysomelid parasitoid M. rubricornis. It not only has the third antennal segments more reddish yellow than brown but these lack the internal vesicles (= subcuticular pit sensilla of Pfeil et al. 1994). Furthermore in both sexes it has only two bristles on the notopleuron and the female's cerci are yellow not brown.

Male: a brown species, with brown abdomi- 
nal venter, hypopygium (including anal tube), legs and antennae. Frons a little wider than midline length. Chaetotaxy as female. Greatest breadth of third antennal segment about $0.15 \mathrm{~mm}$. Internally with at least 20 vesicles of variable size, the largest being only as large as sockets of lower supraantennal bristles. The brown labrum with greatest breadth at most as large as the diameter of third antennal segment. Labella brown, each with 24 30 short spinules below and inconspicuous pale yellow teeth on inner face. Each side of scutum with a humeral, 3 or rarely only 2 notopleurals (when only 2 it is the middle one that is reduced or absent), an intra-alar, a postalar and a prescutellar dorsocentral bristle. The hairs at rear of scutum, between the dorsocentrals, are stronger than those on rest of scutum. With four subequal bristles on scutellum. Hairs on abdominal tergites small, but a little stronger posterolaterally, especially on T2. Those at rear of T6 longer and hypopygium as Fig. 1, but with or without the differentiated small hairs below proctiger. Hairs on segments 3-6 of venter, with those at rear of 6 a little longer. Legs as female but hairs below hind femur a little longer. Spines of hind tibial combs all simple. All five foretarsal segments with a posterodorsal, longitudinal, hair palisade. Neardorsal palisade of mid tibia extends about three quarters of length. Wing 2.1-2.4 mm long. Costal index $0.53-0.55$. Costal ratios $2.94-3.59: 1.50$ 2.07 : 1. Costal cilia $0.12-0.14 \mathrm{~mm}$ long. A small hair at base of vein 3. Axillary ridge with 4-5 bristles, the longest as long as as costal cilia of section 3. Sc fades away just before reaching R1. Veins light greyish brown. Membrane distinctly tinged grey. Haltere with brown stem and largely yellow knob.

Female: additional to the description by Schmitz, the following features are noted. Third antennal segment at least as large as male and with similar vesicles. Labrum more robust and its greatest breadth a little greater than diameter of third antennal segment. Labella very similar to male but with stronger teeth on inner faces. Thoracic chaetotaxy as male, but always with three bristles on notopleuron and anterior scutellars a little shorter than posterior pair. Lobes at rear of abdominal sternum 8 as Fig. 2. Internally with Dufour's crop mechanism situated well forward in thorax and posteriorly bilobed, but the lobes

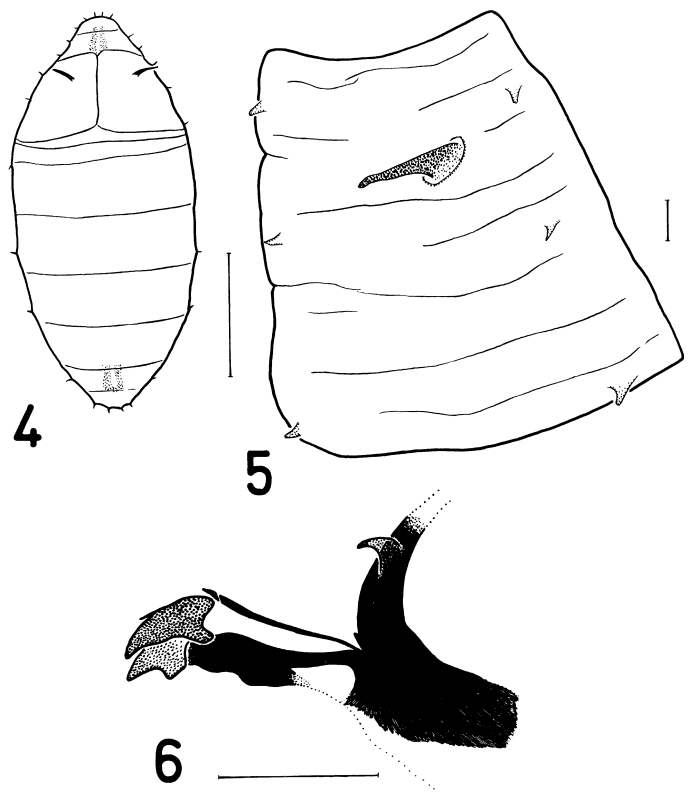

Figs 4-6. Megaselia opacicornis puparium and larval mouthparts. (4) Puparium from above (scale bar $=1$ $\mathrm{mm}$ ); (5) left eclosion plate (scale bar $=0.05 \mathrm{~mm}$ ); (6) left face of last instar cephalopharyngeal skeleton (scale bar $=0.05 \mathrm{~mm}$ ).

are short. The large but irregular vaginal sclerite (furca) variably sclerotised, sometimes being so pale as to be not discernible without critical lighting, and a putative spermatheca usually visible (Fig. 3). Wings 2.36-2.70 mm long. Costal index 0.52-0.59. Costal ratios 2.68-4.01: 1.53-2.07 : 1. Costal cilia $0.12-0.14 \mathrm{~mm}$ long. With $5-6$ axillary bristles.

Puparium (described by MBM): at eclosion the anterior cap and paired eclosion plates are detached separately. The puparium is orange brown, 2.7-3.4 mm long and as Fig. 4. The respiratory horns (Fig. 5) are dark brown to black. The last instar larva's cephalophayngeal skeleton, retained within the anterior cap, is as Fig. 6.

\section{Natural history}

The host beetle, Melasoma lapponica, abounds in the Murmansk Region of Russia, near Monchegorsk, at the base of the Kolsky Peninsula. Despite this region being one of the most extreme examples of terrestrial pollution in the boreal for- 
est zone, due to the Severonikel nickel-copper smelter, populations of the beetle flourish there. This leaf beetle feeds on trees of genera such as Betula, Salix and Populus. The previous studies of this beetle in the vicinity of Monchegorsk report it feeding on six species of willow (Salix spp.), but mainly on S. borealis (Fries) Nazar. The adult beetles hibernate in the soil until the time of leaf flush in mid June. The larvae then feed on mature willow leaves from early July until early August. They then pupate on the leaves. The next generation of beetles emerges in mid August and feeds for a few days before retreating into the soil before the onset of winter.

Megaselia opacicornis females oviposited into prepupae, or occasionally new pupae, in late July to early August. Recorded rates of parasitization ranged up to 0.35 , being higher in the more heavily polluted habitats. Oviposition was at the rear end of the host, which was attached to the leaf, and thus the fly more readily evaded the defensive responses of the mobile anterior end. The eggs were either laid on the surface of the host or on the leaf surface not more than $10 \mathrm{~mm}$ from it. Frequently 2-3 females investigated the same host simultaneously, despite unattended prepupae being close by. The development of the fly larvae took 5-7 days in the laboratory at room temperature. Pupation took place within the host's pupal skin, coinciding with the time of adult eclosion by unparasitized hosts. $1-5$, usually 2 , fly pupae developed from each host pupa. These fly pupae varied in weight from 1-4 mg, depending on the number per host. Outdoors the fly pupae probably overwinter, inside the host pupal skins, amongst the litter of fallen willow leaves.

\section{Discussion}

With the report of Megaselia rubricornis parasitizing Chrysomela (= Melasoma) aenea and now the related M. opacicornis parasitizing Melasoma lapponica, one wonders whether the phorid reported parasitizing $M$. populi was one of these two species of fly or a third related species.

The variation in the number of notopleural bristles in the males of M. opacicornis is unusual. While the notopleural bristle number has proved to be a valuable taxonomic character (e.g. Disney
1989), this case of variation means that one needs to check out any specimen thought to be a new species by keying it both ways from couplets that utilise notopleural bristle number to discriminate two groups of species in this large and complex genus. If, however, a notopleural cleft is present then the option of three bristles can be ruled out.

Acknowledgements. RHLD is grateful to Dr Hans Ulrich (Museum Koenig, Bonn) for the loan of critical specimens in his care. RHLD is currently funded by the Isaac Newton Trust (Trinity College, Cambridge). EZ's studies have been funded by the Maj and Tor Nessling Foundation, Finland.

\section{References}

Borgmeier, T. 1958: Neue Beitraege zur Kenntnis der neotropischen Phoriden (Diptera, Phoridae). - Studia Ent., Petropolis 1: 305-406.

Brown, B. V. 1996a: Preliminary analysis of a host shift: revision of the Neotropical species of Apocephalus, subgenus Mesophora (Diptera: Phoridae). - Contrib. Sci. (Nat. Hist. Mus. Los Angeles Co.) 462: 1-36.

Brown, B. V. 1996b: A. Phorid collecting activities in Ecuador, 1996. B. Complementary collecting techniques. - Phorid Newsletter 5: 1-4.

Devantoy, J. 1948: Les prédateurs et les parasites de la chrysomèle du peuplier. — La Feuille des Naturalistes (N. S.) 3: 85-9.

Disney, R. H. L. 1989: Scuttle flies Diptera, Phoridae genus Megaselia. - Handbks Ident. British Insects 10(8): $1-155$.

Disney, R. H. L. 1994: Scuttle Flies: The Phoridae. Chapman \& Hall, London.

Disney, R. H. L., Majerus, M. E. N. \& Walpole, M. J. 1994: Phoridae (Diptera) parasitising Coccinellidae (Coleoptera). - Entomologist 113: 28-42.

Durska, E. \& Disney, R. H. L. 1998: A scuttle fly (Diptera: Phoridae) reared from a beetle (Coleoptera: Cerambycidae). - Entomologist's Gaz. 49: 269-270.

Kanervo, V. 1946: Tutkimuksia Lepän Lehtikuoriaisen, Melasoma aenea L. (Col., Chrysomelidae), Luontaisista vihollisista. - Annal. Zool. Soc. Zool.-Bot. Fenn. 12: 1-174.

Lewis, S. M. \& Monchamp, J. D. 1994: Sexual and temporal differences in phorid parasitism of Photinus marginellus fireflies (Coleoptera: Lampyridae). — Ann. Ent. Soc. America 87: 572-5.

Lloyd, J. E. 1973: Firefly (Col., Lampyridae) parasites and predators. - Coleopterists' Bull. 27: 91-106.

Pfeil, R. M., Walsh, R. A. \& Mumma, R. O. 1994: Scanning electron microscope examination of the putative olfactory structures possessed by the phorid fly, Megaselia halterata (Diptera, Phoridae). - Scanning Microscopy 8: 687-694. 
Schmitz, H. 1949: Zwei neue Phoriden aus Stiermark und Finland. — Naturhist. Maandblad 38: 78-80.

Schmitz, H. \& Delage, A. 1981: Phoridae. - In Lindner, E. (Ed.): Die Fliegen der palaearktischen Region 4(33) (Lief. 325): 665-712.

Zvereva, E. L., Kozlov, M. V. \& Neuvonen, S. 1995: Popultion density and performance of Melosoma lapponica (Coleoptera: Chrysomelidae) in surroundings of a smelter complex. - Environ. Ent. 24: 707-15.

Zvereva, E. L., Kozlov, M. V. \& Neuvonen, S. 1997: Population dynamics of a herbivore in an industrially modified landscape: case study with Melasoma lapponica (Coleoptera: Chrysomelidae). - Phytopath. Ent. Hungarica 32: 251-8. 